\title{
Inequality in the Selection Process for Candidates for Members of the Indonesian Broadcasting Commission 2019-2022
}

\author{
Supadiyanto \\ Communication Studies Program Yogyakarta College of Communication Sciences, \\ Yogyakarta-Indonesia \\ e-mail: supadiyantostikomyogyakarta@gmail.com
}

\begin{abstract}
The existence of the Indonesian Broadcasting Commission (IBC) is guaranteed by Law of the Republic of Indonesia Number: 32/2002 concerning Broadcasting. In practice, the selection process for the Indonesian Broadcasting Commissioner candidates for the 2019-2022 period was deviated, not transparent, and inconsistent. Logically, the results of the final selection deserve to be questioned by the public. There are two problems. How is the reflective experience of researchers in the selection process of prospective members of the Indonesian Broadcasting Commission 2019-2022? How is the legal effort undertaken by researchers to counter the inconsistencies of law enforcement in the selection process for the Indonesian Broadcasting Commission 2019-2022? The research paradigm is qualitative-empirical-descriptive-juridical. There are two types of data in this study, namely: primary and secondary data. When the research took place from November 2018 to April 2020. As a result, the Selection Committee for Prospective Members of the Indonesian Broadcasting Commission for the 2019-2022 Period, the Ministry of Communication and Information of the Republic of Indonesia was detected to have committed a number of violations of broadcasting regulations. The study of various regulations that were violated has been legally examined. There are three things that are violated, namely the aspects of transparency, inconsistency, and the principle of non-compliance with regulations. The researcher has empirical experience in the selection process of prospective members of the Indonesian Broadcasting Commission for the 2019-2022 Period and experienced injustice in the selection process has launched a legal step by submitting a complaint to the Ombudsman of the Republic of Indonesia and the Jakarta State Administrative Court, and writing an open letter. The aspect of law enforcement in the broadcasting sector is still weak, including in the selection process of prospective members of the Indonesian Broadcasting Commission for the 2019-2022 Period experiencing many weaknesses and legal irregularities. Regulations regarding the selection process for prospective members of the Indonesian Broadcasting Commission must be emphasized and strengthened.
\end{abstract}

Key words: Indonesian Broadcasting Commission, broadcasting, regulation, selection, inconsistent.

\begin{abstract}
Abstrak
Eksistensi Komisi Penyiaran Indonesia dijamin Undang-Undang Republik Indonesia Nomor: 32 Tahun 2002 tentang Penyiaran. Dalam praktiknya, proses seleksi kandidat komisioner Komisi Penyiaran Indonesia periode 2019-2022 mengalami penyimpangan, tidak transparan, dan tidak konsisten. Logislah, hasil seleksi akhir layak dipertanyakan publik. Ada dua masalah. Bagaimana pengalaman reflektif peneliti dalam proses seleksi calon anggota Komisi Penyiaran Indonesia 2019-2022? Bagaimanakah upaya hukum yang dilakukan peneliti untuk melawan inkonsistensi penegakan hukum dalam proses pemilihan kandidat Komisi Penyiaran Indonesia 2019-2022? Paradigma penelitian adalah kualitatif-empiris-deskriptif-yuridis. Ada dua jenis data dalam penelitian yaitu: data primer dan sekunder. Waktu penelitian berlangsung dari November 2018 hingga April 2020. Hasilnya, Panitia Seleksi Calon Anggota Komisi Penyiaran Indonesia Periode 2019-2022, Kementerian Komunikasi dan Informasi Republik Indonesia terdeteksi telah melakukan sejumlah pelanggaran peraturan penyiaran. Studi berbagai peraturan yang dilanggar telah diperiksa secara hukum. Ada tiga hal yang dilanggar, yaitu aspek transparansi, inkonsistensi, dan prinsip ketidakpatuhan terhadap peraturan. Peneliti memiliki pengalaman empiris dalam proses seleksi calon anggota Komisi Penyiaran Indonesia Periode 2019-2022 dan mengalami ketidakadilan dalam proses seleksi telah meluncurkan langkah hukum dengan
\end{abstract}


mengajukan aduan kepada Ombudsman Republik Indonesia dan Pengadilan Tata Usaha Negara Jakarta, dan menulis surat terbuka. Aspek penegakan hukum di sektor penyiaran masih lemah, termasuk dalam proses seleksi calon anggota Komisi Penyiaran Indonesia Periode 2019-2022 mengalami banyak kelemahan dan penyimpangan hukum. Regulasi mengenai proses seleksi untuk calon anggota Komisi Penyiaran Indonesia harus dipertegas dan diperkuat.

\section{Kata-kata kunci: Komisi Penyiaran Indonesia, penyiaran, regulasi, seleksi, tidak konsisten}

\section{Background}

A total of 9 commissioners of the Central Indonesian Broadcasting Commission (IBC) for the 2019-2022 Period have been selected and determined based on the Republic of Indonesia's Presidential Decree Number: 73/P/2019 concerning Dismissal and Appointment of Members of the Central Indonesian Broadcasting Commission (2019-2022) on July 26, 2019. But behind the process selection of candidates for the Central Indonesian Broadcasting Commission for the 2019-2022 Period left a number of irregularities because they were considered not transparent and violated a number of regulations. This of course caused a stir in the public. Various parties through the mass media discussed a number of inconsistencies in the selection process. Even to the legal route, namely the lawsuit through the Jakarta State Administrative Court. Ideally, the selection process is carried out in a professional, accountable, honest, proportionate, democratic and compliant way to the regulations that have been set. Even though the results of the selection have been determined, the researcher intends to reflect back on the selection process; where in the process; The researcher was directly involved as one of the candidates for the Central Indonesian Broadcasting Commission 2019-2022.

The existence of the Indonesian Broadcasting Commission is guaranteed to be based on the Law of the Republic of Indonesia Number: 32/2002 concerning Broadcasting Articles 7 to 12 . That the main task of the Indonesian Broadcasting Commission is to regulate all matters regarding broadcasting and to accommodate aspirations and to represent the interests of the community in broadcasting. That to carry out these responsibilities and mandates requires the presence of Indonesian Broadcast Commission commissioners who are firm, honest, fair, disciplined, and professional.

Public interest to become a commissioner of the Central Indonesian Broadcasting Commission for the 2019-2020 Period is very high. It was proven that since the Selection Committee for Prospective Members of the Central Indonesian Broadcasting Commission for the 20192022 Period opened registration from 5-25 November 2019, there were hundreds of registrants and those who were declared to have met administrative requirements were 
only 207 participants. After the paper selection test, there were only 54 participants who passed this stage. Those who pass the paper writing stage are entitled to take the next step: Psychological Assessment and Minnesota Multiphasic Personality Inventory Test (MMPI). At this stage there were 49 people who passed the stage, where they were entitled to participate in the next stage of selection which was an interview before the Selection Committee for Prospective Members of the Indonesian Broadcasting Commission 2019-2022 in the Aryaduta Hotel Jakarta on 4-5 March 2019. Where the results passed 34 participants were proposed to take part in a public test at the House of Representatives of the Republic of Indonesia on 8-10 July 2019. Finally, 9 permanent names were elected as commissioners, as stated in the Presidential Decree of the Republic of Indonesia Number: 73/P/2019 concerning Dismissal and Appointment of Members Central Indonesian Broadcasting Commission (2019-2022) on July 26, 2019.

Based on experience, observations, and tracing various sources of literature, researchers found a number of evidence, that in the selection process found a number of irregularities and violations of the regulations that will be discussed in this study. This research departs from the experience of researchers involved directly in the selection process of prospective members of the Central Indonesian Broadcasting Commission for the 20192022 Period and a strong desire to enforce broadcast media regulations. There are two big problems in this research. First, how is the reflection of researchers in the practice of selecting candidates for members of the Central Indonesian Broadcasting Commission 2019-2022? How is the legal effort that has been carried out by researchers when experiencing injustice and inconsistency in regulation in the selection practice of prospective members of the Indonesian Broadcasting Commission for the 2019-2022 Period?

A review of the professional work of the commissioners of the Indonesian Broadcasting Commission has been carried out by a number of researchers. Among others: Dian Sukmawati and Ade Armando (2019) in a study entitled: Indonesian Broadcasting Commission Authority in Broadcast Content Management in Global Communication Journal Volume 8 Number 2 of 2019 shows that the commissioners of the Indonesian Broadcasting Commission of the present period are more compromised with private television stations. In fact, the Indonesian Broadcasting Commission prefers to provide guidance through dialogue rather than sanctioning written reprimands or even sanctions to terminate 
the program. This fact proves that the position as a commissioner is only a stepping stone for greater power. Another researcher, Nurly Meilinda in www.researchgate.net entitled: Indonesian Broadcasting Commission in Political Economy Snares shows that the weak enforcement of broadcasting regulations and the poor performance of the Indonesian Broadcasting Commission is currently due to the results of a battle of interests of political and economic actors including: the government, the House of Representatives The People of the Republic of Indonesia, private television stations, and the Indonesian Broadcasting Commission which adapt to the sociopolitical context and Indonesian style of democracy.

It is interesting to examine the results of research by Denico Doly (2015), which tried to offer three legal measures to strengthen the institutional broadcasting of the Indonesian Broadcasting Commission which has so far been weakened to be more legally sturdy. Efforts to strengthen the Indonesian Broadcasting Commission's institutions need to be done by reforming the Indonesian Broadcasting Commission, namely by emphasizing the institutional broadcasting of the Indonesian Broadcasting Commission, changing the institutional structure of the Indonesian Broadcasting Commission, and providing legal instruments that can support the performance of the Indonesian Broadcasting Commission. One big problem is that: the process of selecting members of the Indonesian Broadcasting Commission has not been explicitly regulated in Law of the Republic of Indonesia Number 32 of 2002 concerning Broadcasting. Regarding the functions, duties and authority of the Indonesian Broadcasting Commission, it also has not comprehensively anticipated the development of technology in the field of digital broadcasting and the Internet. Moreover, broadcasting technology also leads to the realm of social media which is completely untouched by regulation.

Even the authority of the Indonesian Broadcasting Commission has become very limited, given its existence is less prestigious than the television program rating agency. This is relevant to the results of research conducted by Agus Maladi Irianto (2011), revealing that the existence of the Indonesian Broadcasting Commission as a broadcasting regulation holder was apparently unable to regulate the level of television station broadcast competition. Law Number 32 of 2002 concerning Broadcasting, whose idea is a reference for regulating the television broadcasting industry in Indonesia, is even more "defeated" by TV rating. TV rating is a measurement of television audience presentations conducted by Nielsen Media Research (NMR) using a monitoring tool 
called Peoplemeter. From these tools will be known about human activities in relation to television shows; when the time is watching, the television channel being watched, and who is watching. It is also part of the knowledge system and the production system which contains the intentions and desires of the user. In the desire of the user, power relations are stored, both between the social situation in which the technology is used and the condition of the users in other places which are then situated. Say, when the peoplemeter produces a series of figures in the form of audience ratings, a number of television station managers also develop their respective strategies for the shows they present. Like clockwork, the numbers pointed to by the peoplemeter have meaning about the actions that humans must take. Thus it can be said that the existence of the Indonesian Broadcasting Commission has not been able to become an authoritative "referee" in overcoming the competition of a number of television station shows in Indonesia.

Annisa Haismaida's research (2017) reinforces that in the selection process the members of the Indonesian Broadcasting Commission commissioner were not in accordance with the rules and there were allegations of political party interference. This happened when he first started entering the democratic party in the 2014 General
Election. The results of his research of the news that appeared on the Main Page of the Tempo Magazine January 20-26, 2014 edition proved this. The headline in question is: Broadcast Retrieval Gratuitous Selection; No-use exams; Birth Defects; Hit the Rules of Hit; Senayan Shadow Team; Air Strike on the Screen; and Loyo Face the Kick of Advertising.

Serious issues that must actually be "sued" are actually related to the authority of the Indonesian Broadcasting Commission. The Indonesian Broadcasting Commission as a representative of the people (community) in the broadcasting field, means that its position is in line with the existence of representatives in the legislature, it should have full authority to regulate the Broadcasting Permit (including licensing). The existence of dualism in the field of broadcasting licensing, which has been a trigger for the low authority and bargaining position of the Central and Regional Indonesian Broadcasting Commission in the eyes of the managers of Broadcasting Institutions (Public Broadcasting Institutions, Private Broadcasting Institutions, Subscribed Broadcasting Institutions, and Community Broadcasting Institutions). The courage of the commissioners of the new Indonesian Broadcasting Commission must be brave in supporting the strengthening of the Central 
and Regional Indonesian Broadcasting Commission institutions through reforming the new broadcasting regulations by including the clauses of the Central and Regional Indonesian Broadcasting Commissions having full authority to grant or revoke Broadcasting Licenses (new and extended).

Other studies regarding the problem of the existence of the Indonesian Broadcasting Commission and professionalism in the selection process of prospective members of the Central Indonesian Broadcasting Commission have never existed, as long as the data search carried out by researchers up to now. For this reason, this research has a novelty in terms of data and empirical facts from researchers who have experience participating in selection as a prospective member of the Central Indonesian Broadcasting Commission for the 20192022 Period and making a lawsuit against injustice in the selection process.

\section{Methodology}

The paradigm of this research is qualitative-empirical-descriptive-juridical.

There are two types of data processed in this study, namely: primary and secondary data. Primary data sourced from the experience of researchers as direct actors who are the center of this research. Because he was a participant in the selection of candidates for the Indonesian Broadcasting Commission
2019-2022. Secondary data is taken from various regulations governing the broadcasting world, and selection regulations for prospective members of the Indonesian Broadcasting Commission. Other data sources were sourced from the results of the Jakarta State Administrative Court, recommendations from the Ombudsman of the Republic of Indonesia, and other sources. The time of this research took place from November 2018 to December 2019. As a result, the Selection Committee for Prospective Members of the Indonesian Broadcasting Commission for the 2019-2022 Period, the Ministry of Communication and Information of the Republic of Indonesia was detected as having committed a number of violations of broadcasting regulations.

Data analysis was carried out by reflecting the experience of researchers in following all stages of the selection process for prospective members of the Indonesian Broadcasting Commission 2020-2023 conducted by the Indonesian Broadcasting Commission Candidate Selection Committee 2019-2020. Various important documents and data in the form of regulations and literature reviews that are relevant to the research topic. All types of data are processed and analyzed to answer the main problematic problems revealed in this study. Data analysis is based on the legal study of broadcast media regulations and 
empirical experience in participating in the selection process of prospective members of the Indonesian Broadcasting Commission, and followed by conducting social movements through lawsuits at the Jakarta State Administrative Court and the Ombudsman of the Republic of Indonesia, becoming an applied research to enforce broadcasting law in Indonesia. The results are expected to be a new style of research model that is implementative and able to provide enlightenment for the public.

\section{Research Result and Discussion}

\section{Empirical reflection on the selection practices of prospective members of the} Central Indonesian Broadcasting Commission 2019-2022

The interest of researchers is directly involved in the selection of prospective members of the Central Indonesian Broadcasting Commission for the 20192022 Period as a form of commitment and responsibility of researchers in efforts to enforce broadcasting law. Encouragement from various parties to researchers to participate in contestation and participate in strengthening the existence of an independent state institution called the Indonesian Broadcasting Commission began from his service as a commissioner of the Indonesian Broadcasting Commission of the
Special Region of Yogyakarta in the 20142017 period. This spirit has become a motivator and motivator for researchers to fight in the field of broadcasting law enforcement, especially by wanting to become a commissioner of the Central Indonesian Broadcasting Commission for the 2019-2022 Period. However, various obstacles and obstacles as well as the inconsistency of the Selection Committee for Prospective Members of the Central Indonesian Broadcasting Commission 20192022 experienced by researchers, finally made a failure in the selection process.

The following is explained a number of legal facts that cause why researchers consider that the process of prospective members of the Central Indonesian Broadcasting Commission 2019-2022 Period does not comply with regulations and is less professional. First, the formation of the Selection Committee by the Minister of Communication and Information has violated the Regulation of the Indonesian Broadcasting Commission Number: 01/P/KPI/07/2014 concerning the Institution of the Indonesian Broadcasting Commission, as stipulated in Article 9 paragraph (1), (2) and paragraph (3) and Article 10 paragraph (1) and (4) as follows:

Article 9: (1) Members of the Central Indonesian Broadcasting Commission are elected by the House of Representatives of 
the Republic of Indonesia at the suggestion of the public through an open fit and proper test. (2) Members of the Central Indonesian Broadcasting Commission are administratively appointed by the President at the proposal of the House of Representatives of the Republic of Indonesia. (3) The House of Representatives of the Republic of Indonesia may be assisted by the Selection Team for the Selection of Members of the Central Indonesian Broadcasting Commission who reports directly to the House of Representatives of the Republic of Indonesia.

Article 10: (1) The selection of the Selection Team for the selection of members of the Central Indonesian Broadcasting Commission shall be carried out by the House of Representatives of the Republic of Indonesia. (4) Decree on the Determination of the Selection Team for the Selection of Members of the Central Indonesian Broadcasting Commission shall be prepared and signed by the House of Representatives of the Republic of Indonesia.

Based on the above provisions, the selection committee for Candidates for Members of the Central Indonesian Broadcasting Commission is directly responsible to the House of Representatives of the Republic of Indonesia; not a Selection Committee for Prospective Members of the Central Indonesian Broadcasting Commission formed and reporting to the
Minister of Communication and Information of the Republic of Indonesia. Therefore the formation of a selection committee by the Minister of Communication and Information of the Republic of Indonesia has violated the Regulation of the Indonesian Broadcasting Commission Number: 01/P/KPI/07/2014. That in its nomenclature, the relationship between the Ministry of Communication and Information of the Republic of Indonesia and the Central Indonesian Broadcasting Commission is equal or a partner. Not a hierarchical model. This means that the Selection Committee for Prospective Members of the Central Indonesian Broadcasting Commission for the 20192022 Period established by the Minister of Communication and Information of the Republic of Indonesia does not necessarily have the authority under the statutory law to select candidates for the 2019 Central Indonesian Broadcasting Commission.

Supposedly, the Selection Committee for Candidates for Members of the Central Indonesian Broadcasting Commission for the 2019-2022 Period and beyond is formed directly by the House of Representatives of the Republic of Indonesia. This is relevant to the mandate of the Law of the Republic of Indonesia Number: 32/2002 concerning Broadcasting Article 7 paragraph 4: "In carrying out its functions, duties, authorities and obligations, the Central Indonesian Broadcasting Commission is overseen by 
the House of Representatives of the Republic of Indonesia, and the Regional Indonesian Broadcasting Commission overseen by the Provincial Regional House of Representatives". Law of the Republic of Indonesia Number: 32/2002 regarding Broadcasting Article 10 paragraph 3: "Members of the Central Indonesian Broadcasting Commission are administratively determined by the President on the proposal of the House of Representatives of the Republic of Indonesia and members of the Regional Indonesian Broadcasting Commission are administratively determined by the Governor at the proposal of the House of Representatives Provincial Region ". The above facts also contradict the Law of the Republic of Indonesia Number: 30/2014 concerning Government Administration Article 17 paragraphs 1 and 2. It reads: "(1) Government bodies and or officials are prohibited from abusing authority". Prohibition of abuse of authority as referred to in paragraph (1) includes: a. prohibition beyond authority, b. prohibition on mixing authority and or c. prohibition of arbitrary actions ".

Second, the number of members of the Selection Committee for Candidates for Members of the Central Indonesian Broadcasting Commission for the 20192022 Period amounting to 17 people as stated in the Decree of the Minister of Communication and Information of the Republic of Indonesia Number: 798/2018 concerning the Candidate Selection Committee for the Members of the Central Indonesian Broadcasting Commission for the 2019-2022 Period; which subsequently was revised to 16 people as stated in the Decree of the Minister of Communication and Information of the Republic of Indonesia Number: 115/2019 concerning Amendment to the Decree of the Minister of Communication and Information Number: 798/2018 concerning the Selection Committee for Candidates for Members of the Central Indonesian Broadcasting Commission 2019-2022; clearly contrary to the Regulation of the Indonesian Broadcasting Commission Number: 01/P/KPI/07/2014 concerning the Institution of the Indonesian Broadcasting Commission Article 10 paragraph 3. Whereas: "The selection team for the selection of members of the Central Indonesian Broadcasting Commission consists of 5 (five) elected members and stipulated by the House of Representatives of the Republic of Indonesia by taking into account the representation of elements of community leaders, academics/campus, government, and the Central Indonesian Broadcasting Commission". 
Third, the Decree of the Minister of Communication and Information Technology of the Republic of Indonesia, the Selection Committee for Prospective Members of the Central Indonesian Broadcasting Commission for the 20192022 Period, and the House of Representatives of the Republic of Indonesia Commission 1 which has set 34 names entitled to take due diligence and compliance on 8-10 July 2019, also contrary to the Regulation of the Indonesian Broadcasting Commission Number: 01/P/KPI/07/2014 concerning the Institution of the Indonesian Broadcasting Commission Article 14 paragraph 2. Whereas: "Candidates who take fit and proper test are 3 times or at least 2 times the number of members of the Commission Indonesian Broadcasting Center to be determined". Whereas in accordance with the regulation, the maximum number of candidates for the Central Indonesian Broadcasting Commission for the 2019-2022 Period has the right to take the fit and proper test before the House of Representatives of the Republic of Indonesia is 27 people (derived from the number of members of the Central Indonesian Broadcasting Commission which is 9 times multiplied by multiples of $3)$. In accordance with the mandate of the Law of the Republic of Indonesia Number: 32/2002 concerning Broadcasting Article 10 point e: that "To be appointed as a member of the Indonesian Broadcasting Commission, the following conditions must be met: when authoritative, honest, fair, and behaves without reproach". The Selection Committee for Prospective Members of the Central Indonesian Broadcasting Commission Commission for the 2019-2022 Period is obliged to carry out a full and totality trace of the track record of all prospective members of the Central Indonesian Broadcasting Commission for the 2019-2022 Period.

The above facts also contradict the Law of the Republic of Indonesia Number: 30/2014 concerning Government Administration Article 17 paragraphs 1 and 2. It reads: "(1) Government bodies and or officials are prohibited from abusing authority". (2) Prohibition of abuse of authority as referred to in paragraph (1) includes: a. prohibition beyond authority, b. prohibition on mixing authority and or c. prohibition of arbitrary actions ".

Fourth, based on Press Release Number: 120/HM/KOMINFO/06/2019 dated June 28, 2019 issued by the Ministry of Communication and Information of the Republic of Indonesia to admit honestly that the determination of 7 (seven) incumbent's names which were declared to have passed the fit and proper test on the Board Representatives of the Republic of Indonesia from 34 names of candidates for the Central Indonesian Broadcasting Commission 2019- 
2022 Period-namely referring to and subject to the provisions of Article 13 paragraph 8 of the Regulation of the Indonesian Broadcasting Commission Number: 01/P/KPI/07/2014 concerning the Institution of the Indonesian Broadcasting Commission. However, this is at the same time contrary to the Regulation of the Indonesian Broadcasting Commission Number: 01/P/KPI/07/2014 concerning the Institution of the Indonesian Broadcasting Commission Article 14 paragraph 2. In fact, incumbents who pass the administration are also required to follow the selection stages as other participants, not directly followed the fit and proper test at the House of Representatives of the Republic of Indonesia. The number of due diligence and suitability participants in the House of Representatives of the Republic of Indonesia also exceeds the maximum allowed by the regulation.

Fifth, the Selection Committee for Candidates for Members of the Central Indonesian Broadcasting Commission for the 2019-2022 Period established by the Minister of Communication and Information of the Republic of Indonesia has conducted maladministration and violated a number of regulations in carrying out the selection process for Candidates for the Central Indonesian Broadcasting Commission Members for the 2019-2022 Period. The absence of technical instructions or Standard Operating Procedures regarding the selection mechanism for prospective members of the Central Indonesian Broadcasting Commission for the 20192022 Period; and there is no standard evaluation standard used as a reference to determine the names of selection participants who pass or go to the next stage. Thus, the Selection Committee for Candidates for Members of the Central Indonesian Broadcasting Commission for the 2019-2022 Period formed by the Minister of Communication and Information of the Republic of Indonesia and the Minister of Communication and Information of the Republic of Indonesia jointly surpassed the authority in the selection process of prospective members of the Central Indonesian Broadcasting Commission for the 2019-2022 Period which has made its own rules through agreements that are not regulated in the Law above, namely Law of the Republic of Indonesia Number: 32/2002 concerning Broadcasting.

Finally, that the matter of transparency carried out by the Selection Committee for Candidates for Members of the Central Indonesian Broadcasting Commission for the 2019-2022 Period in the selection process, especially at the interview selection stage, including the work stages and plenary 
results of March 5, 2019; it was found that the alleged search results conducted by the Financial Transaction Reports and Analysis Center on suspicious fund flows involving incumbents. That the results of the tracking of the Financial Transaction Reports and Analysis Center for the 48 candidates for the Central Indonesian Broadcasting Commission for the 2019-2022 Period who participated in the interview selection must be made public. The results of the assessment (score) and ranking of interviews with 48 prospective members of the Central Indonesian Broadcasting Commission for the 2019-2022 Period — which became the legal basis for the final plenary determination of the Selection Committee for Candidates for the Members of the Central Indonesian Broadcasting Commission for the 2019-2022 Central Period must also be made public. Until the selection is over, the Selection Committee for Prospective Members of the Central Indonesian Broadcasting Commission for the 2019-2022 Period and the Ministry of Communication and Information of the Republic of Indonesia will never publish these facts. The researcher considers that the assessment is not objective and fair, because the information obtained from the results of "investigation"; at the plenary meeting on March 5, 2019, there were 27 lists of names that had passed (in which the name of the researcher was confirmed to be one of the 27 lists); but then after the list of names was given to the Republic of Indonesia Ministry of Communication and Information then it changed to 34 names; as stipulated in the Decree of the Minister of Communication and Information of the Republic of Indonesia Number: R476/M.KOMINFO/KP.03.01/06/2019 dated June 19, 2019 containing 34 candidates for the Central Indonesian Broadcasting Commission for the 2019-2022 Period. Based on this letter, the House of Representatives of the Republic of Indonesia Commission 1 issued Decree on 34 Prospective Members of the Central Indonesian Broadcasting Commission for the 2019-2022 Period on June 20, 2019; which was later published through Kompas June 26, 2019 edition. Information that had been obtained by researchers, that the Ministry of Communication and Information of the Republic of Indonesia was allegedly made a small team outside the Selection Committee for Prospective Members of the Central Indonesian Broadcasting Commission for the 2019-2022 Period consisting of 5 parties. The task of the small team was to examine the track record of all participants who took part in the interview from the tracking side of the Financial Transaction Reports and Analysis Center. The small team was also reported to have invited several broadcast industry groups, namely: the Indonesian Private Television 
Association, the Indonesian National Private Broadcast Radio Association, and the Indonesian Television Journalists Association to be asked for opinions regarding the list of names to be passed to the House of Representatives of the Republic of Indonesia. If this is true, it means that the credibility and integrity of the Selection Committee for Prospective Members of the Central Indonesian Broadcasting Commission for the 20192022 Period has been intervened by outsiders.

Based on the findings and legal facts, the researcher is determined to take legal steps because he personally feels disadvantaged in the selection process. The legal steps that researchers do are in the next section.

Lawsuit in the Jakarta State Administrative Court, a step to enforce regulation in the selection of candidates for Indonesian Broadcasting Commission Members 2019-2022

After being declared not qualified to participate in the final stage of the fit and proper test in the House of Representatives of the Republic of Indonesia, the researcher as one of the participants who saw a number of irregularities in the selection process carried out a number of legal steps including:

One, researchers have written an Open Letter to the President of the Republic of Indonesia related to the Selection of
Prospective Members of the Central Indonesian Broadcasting Commission for the 2019-2022 Period on June 23, 2019 via e-mail and facebook. The letter can be accessed via:https://www.facebook.com/permalink.p hp?story_fbid=973428432996203\&id=100 009871664700. The letter was also sent by e-mail to: the House of Representatives of the Republic of Indonesia, the Ministry of Communication and Information of the Republic of Indonesia, and the Central Indonesian Broadcasting Commission. The letter was also published by Pewarta Indonesia Online Koran edition 24 June 2019 or can be accessed via: https://pewartaindonesia.com/2019/06/surat-terbukauntuk-presiden-ri-terkait-seleksi-calonanggota- commissioner-kpi-center-20192022 /. Various print and online media and then widely publicized the letter.

Two, together with one of the other participants who were declared not qualified to take the final stage (Sapardiyono) made a complaint to the Ombudsman of the Republic of Indonesia on June 27, 2020. This legal step was a strategic step, because it managed to get strong support from the Ombudsman of the Republic of Indonesia, a number of associations, public observers of the broadcasting world, and get intensive mass media coverage starting from Kompas, Tempo and other media. 
Based on the Final Report on Examination Results Registration 0277/LM/VII/2019/JKT Regarding

Allegations of Exceeding Authority by the Selection Committee in the Selection Process of Central KPI Members Period 2019-2022 published in September 2019, found an important fact that the Ombudsman of the Republic of Indonesia concluded that it had been found maladinistration in the form of exceeding the authority carried out by the Selection Committee of Indonesian Broadcasting Commission Members for the 2019-2022 Period because it has made its own rules through an agreement that is not regulated in the Act.

Three, the researcher sent an idea entitled: Criticizing the Selection Process of the Indonesian Broadcasting Commission and published in the July 13, 2019 edition of Jakarta Newspaper, clickable: http://www.koran-jakarta.com/mengkritisiprocess-seleksi-kpi/.

Four, researchers through Ahmad, S.H., M.H. (lawyer) officially registered a lawsuit against the Minister of Communication and Information of the Republic of Indonesia at the Jakarta State Administrative Court on July 25, 2019. As from July 2019-December 2019 the trial process at the Jakarta State Administrative Court took place, and it was decided on December 5, 2019 with a panel of judges led by Baiq Yuliani, SH (Chief Justice), Nelvy Christin, S.H., M.H. (Judge
Member), and Taufiq Perdana, S.H., M.H. (Judge Member) and Sumaja, S.H. (Substitute Registrar). The results of the Court's Decision Number: $152 / \mathrm{G} / 2019 / \mathrm{PTUN}-J K T$ related to the lawsuit the researcher was very disappointing for prosecutors of justice. That the Jakarta State Administrative Court stated that the plaintiff's claim was not accepted and accepted the defendant's exception regarding the absolute authority of the court, and at the same time the Jakarta State Administrative Court was not in absolute authority to adjudicate the a quo dispute or in a dispute against the claim the researcher submitted. If the verdict is so, then if the Jakarta State Administrative Court states that it does not have the authority to adjudicate the lawsuit of the researcher, then where should the researcher submit his claim related to law enforcement efforts in the selection process of prospective members of the Central Indonesian Broadcasting Commission for the 2019-2022 Period. There is still hope indeed, namely by taking legal action namely an appeal to the State Administrative High Court. But it takes even greater and harsh struggle, both in terms of physical, financial, intellectualism, and networking.

The existence of thought support and material assistance from comrades in arms as long as the researchers launched a lawsuit in the Jakarta State Administrative Court, 
has really become a big lesson in broadcasting law enforcement efforts in Indonesia.

\section{Conclusion}

In fact, the selection of Candidates for Members of the Central Indonesian Broadcasting Commission 2019-2022 has produced 9 selected commissioners namely: Nuning Rodiyah, Mulyo Hadi Purnomo, Aswar Hasan, Agung Suprio, Yuliandre Darwis, Hardly Stefano Fenelon Pariela, Irsal Ambia, Mimah Susanti, and Mohamad Reza.

Behind the selection process, has caused a public uproar, considering the selection process is done by not complying with a number of regulations in particular Indonesian Broadcasting Commission Regulation Number: 01/P/KPI/07/2014 concerning the Institutions of the Indonesian Broadcasting Commission, as stipulated in Article 9 paragraph (1), (2) and paragraph (3) and Article 10 paragraph (1) and (4). This is a negative historical record in the selection of candidates for the Central Indonesian Broadcasting Commission for the 20192022 Period. In the recruitment of prospective members of the Indonesian Broadcasting Commission the previous period, also experienced the same thing. The reason is simple, the Selection Committee for Candidates for Members of the Central
Indonesian Broadcasting Commission did not make the Indonesian Broadcasting Commission Regulation Number: 01/P/KPI/07/2014 concerning the Institution of the Indonesian Broadcasting Commission as a legal basis and guidance in the selection process. Legal arguments made by the Ministry of Communication and Information of the Republic of Indonesia (through the results of the study of the Legal Section of the Directorate General of the Implementation of Post and Information Communication and Information Technology) which states that the above regulations do not have binding power, on the pretext of not having a referral to the Law that instructs to regulate the institutions of the Indonesian Broadcasting Commission. On another aspect, the Law of the Republic of Indonesia Number 32 Year 2002 concerning Broadcasting also does not specifically regulate the selection system. In the Act only regulates in general, more specifically only regulates the change of time. This is one of the weaknesses of the Act. Then it should be that the Indonesian Broadcasting Commission Regulation Number: 01/P/KPI/07/2014 concerning the Institution of the Indonesian Broadcasting Commission becomes the main guide in the selection system.

Considering that there have been a number of violations of regulations in the 
selection process of prospective members of the Central Indonesian Broadcasting Commission for the 2019-2022 Period, researchers as one of the selection participants took a legal suit to become a joint lesson. Although the results of the lawsuit have not resulted in a decision as expected by researchers. However, the enthusiasm and commitment that runs during the litigation is truly a commitment to realize the existence of a strong and professional Indonesian Broadcasting Commission. The finding of maladministration in the selection process by the Ombudsman of the Republic of Indonesia, should be a legal finding that must be appreciated and obeyed by the Selection Committee for Candidates for Members of the Central Indonesian Broadcasting Commission for the 20192022 Period, so that it becomes a valuable lesson for the House of Representatives of the Republic of Indonesia, the Ministry of Communication and Information Republic of Indonesia, and President of the Republic of Indonesia.

The legal steps that the researchers took by filing a lawsuit with the Minister of Communication and Information of the Republic of Indonesia at the Jakarta State Administrative Court were deemed appropriate. But it requires expensive costs and energy, for justice seekers. In the future, in order to avoid violations of a number of regulations in the selection of the Central Indonesian Broadcasting Commission for the Period of 2022-2025 and in the following period, the House of Representatives of the Republic of Indonesia and other relevant parties must comply with the regulations in force above, not by making agreements and consensus itself, according to individual policies. The revision of the Law of the Republic of Indonesia Number: 32/2002 concerning Broadcasting must be hastened, with one of its contents namely providing systematic and regulative guidance on the selection process for prospective members of the Central Indonesian Broadcasting Commission in a systematic, democratic, fair, honest and professional manner.

The House of Representatives of the Republic of Indonesia must immediately issue the Law of the Republic of Indonesia concerning Digital Broadcasting which comprehensively regulates the digital broadcast media industry, including regulating the institutions of the Indonesian Broadcasting Commission; so that there is no legal imbalance in the selection of prospective members of the Indonesian Broadcasting Commission in the future.

\section{Appreciation}

We would like to thank the Yogyakarta College of Communication Science, the Alliance of Independent Journalists, Remotivi, the Legal Aid Institute for the 
Press, the Indonesian Citizens Association, and fellow broadcasters activists who have been willing to assist researchers in launching lawsuits in the State Administrative Court Jakarta. The movement could not have been realized without great participation from the parties mentioned above.

Thank you to lawyer Ahmad, M.H. who are willing to work hard constructing various legal facts and fight alone against a coalition team of lawyers owned by the Ministry of Communication and Information of the Republic of Indonesia. Although the end result is not yet as expected, our struggle together may be a lesson for broadcasting law enforcement efforts in Indonesia. We also appreciate the various mass media that publish various news and information related to the selection process of prospective members of the Central Indonesian Broadcasting Commission for the 2019-2022 Period. And thank you to the editor of the Interaction Journal of Muhammadiyah University of North Sumatra for publishing this research.

\section{References}

Court

Decision

Number: 152/G/2019/PTUN-JKT.

Decree of the Minister of Communication and Information of the Republic of Indonesia Number: 798/2018 concerning the Selection Committee for Candidates for Members of the Central IBC for the 2019-2022 Period.
Decree of the Minister of Communication and Information of the Republic of Indonesia Number: 115/2019 concerning Amendment to the Minister of Communication and Information Number: 798/2018 concerning Selection Committee for Candidates for Members of the Central IBC for the 2019-2022 Period.

Doly, Denico. (2015). Institutional Strengthening Efforts of the Indonesian Broadcasting Commission in Legal Perspectives. State Journal of Law Vol. 6 No. 2, November 2015. click: https://www.mendeley.com/catalogue/86 6a3225-8e48-3485-bbee-f50a402766b2/ and http://jurnal.dpr.go.id/index.php/hukum/a rticle/view/252

Final Report on Examination Results Registration Number: 0277/LM/VII/2019/JKT Regarding Allegations of Exceeding Authority by the Selection Committee in the Selection Process of Members of the Central IBC for the 2019-2022 Period.

Haismaida, Annisa. (2017). Media and political relations: analysis of critical discourse on selection of members of the Indonesian Broadcasting Commission Commissioner in reporting the political tactics of the Tempo Magazine television station. Thesis at the Da'wah Faculty and Communication Sciences of UIN Syarif Hidayatullah Jakarta. Click: http://repository.uinjkt.ac.id/dspace/bitstr eam/123456789/34783/1/ANNISA\%20H AISMAIDA-FDK.pdf

https://pewartaindonesia.com/2019/06/surat-terbuka-forpresiden-ri-related-seleksi-calonanggota-komisioner-kpi-pusat-20192022/

IBC Regulation Number: 01/P/KPI/07/2014 concerning the Institution of the Indonesian Broadcasting Commission.

Law of the Republic of Indonesia Number: 30/2014 concerning Government Administration. 
Law of the Republic of Indonesia Number: 32/2002 concerning Broadcasting.

Maladi Irianto, Agus. (2011). Media Construction, Multiculturalism, and the Existence of Broadcasting Laws in Indonesia. Journal of Legal Issues (MMH) Volume 40 No. 3, July 2011. pages 279290.

Click: https://www.mendeley.com/catalogue/d9 c1fa33-1ca1-3385-931f-9ad481410e96/

Meilinda, Nurly, IBC in the Context of Political Economy Fighting. (2019). accessed from: https://www.researchgate.net/profile/Nurl y_Meilinda2/publication/339336068_Ko misi_Penyiaran_Indonesia_dalam_Jerat_ Pertarungan_Ekonomi_Politik/links4337 27272 -Fighting-Economy-Politics.pdf

Presidential Decree of the Republic of Indonesia Number: 73/P/2019 concerning Dismissal and Appointment of Members of the Central IBC (2019-2022).

Press Release Number: 120/HM/KOMINFO/06/2019.

Sukmawati, Dian and Ade Armando. (2019). IBC Authorities in Broadcast Content Arrangements. Journal of Global Communications Volume 8 Number 2, 2019.

Supadiyanto, Supadiyanto's Lawsuit against the Minister of Communication and Information of the Republic of Indonesia in the Dispute on the Selection of the Candidates of the Central IBC Members for the 2019-2022 Period, 2019.

Supadiyanto. (2018). The Future of Indonesia Is Risen or Bankrupt (Prism of Progressive Thought in Various Newspapers). Semarang: Sukarno Pressindo Publisher.

Supadiyanto. July 13, 2019 edition. Criticizing the Selection Process of the IBC. Jakarta newspaper. can be accessed: http://www.koranjakarta.com/mengkritisi-process-seleksikpi/. 